\title{
Elit labdarúgó akadémia utánpótlás játékosai személyiségdimenzióinak összehasonlító vizsgálata nem sportolókkal
}

\section{Analysing Personality of Elite Football Academy Youth Players Compared with Those not Engaged in Competitive Sports}

\author{
Kiss Zoltán1, Csáki István ${ }^{1,2}$, Fózer-Selmeci Barbara³ ${ }^{3}$ Bognár József 2,4 \\ 1 Puskás Ferenc Labdarúgó Akadémia, Felcsút \\ 2 Testnevelési Egyetem, Edzéselméleti és Módszertani Kutató Központ, Budapest \\ 3 Testnevelési Egyetem, Pszichológia és Sportpszichológia Tanszék, Budapest \\ 4 Eszterházy Károly Egyetem, Sporttudományi Intézet, Eger
}

Absztrakt: A labdarúgó tehetséggondozás komplex folyamat, melynek sikerességére több tényezó is hatással van. Több kutatás is beszámol arról, hogy a személyiségtényezők a labdarúgó tehetség kibontakoztatását befolyásoló faktorok (Williams és Franks, 1998). A vizsgálat célja az elit utánpótlás labdarúgók és a nem rendszeresen sportoló fiatalok személyiségdimenziója közötti különbségek és hasonlóságok bemutatása. A személyiség megragadására alkalmas módszer az alapvetó dimenziók kijelölése és számadatokkal való kifejezése (Kozéki, 1988). A vizsgálatot Magyarország egyik elit labdarúgó akadémiáján végeztük, az Eysenck-féle HJEPQ és HEIVEQ (IKE) személyiségtesztek alkalmazásával. Az eredmények alapján elmondhatjuk, hogy a fiatal labdarúgók több személyiségfaktorban is különböző értéket mutattak a nem sportoló fiatalokkal összevetve. Szignifikáns különbség mutatkozott az extraverzió, neuroticizmus, szociális konformitás és a kockázatvállalás alskálák tekintetében. A vizsgált dimenziók ismerete nemcsak a viselkedészavarok megelőzésében, de a nevelés eredményességének növelésében is jelentőséggel bír. Az értékelt adatok alapján ajánlásokat, javaslatokat tehetünk az edzók és a tanárok számára a nevelési módszereik tárházának bővítésére.

Kulcsszavak: fiatal labdarúgók, tehetséggondozás, személyiségdimenziók, nevelés

Abstract: Caring for football talent is a complex process, and the success of this process is influenced by many different factors. Research has shown that personal features are factors influencing the development of football talents (Williams and Franks, 1998). The aim of our study is to compare and contrast the personalities of youth elite players and young people of similar age who are not engaged in competitive sport. In order to track the personalities, we use a method in which we observe the basic dimensions of a personality and try to express them in numbers (Kozéki 1988). Our research was carried out at one of Hungary's elite football academies, using the Eysenck type HJEPQ and HEIVEQ (IKE) personality tests. Our results show that there is a significant difference between the values of the two groups in a number of psychological items. Significant differences were found in extroversion, neuroticism, social conformity and risk taking. Knowing these differences has of great importance in preventing behavioural problems, or providing more effective educational methods. Based on the gained data coaches and teachers can broaden their inventory of teaching methods.

Keywords: young football players, talent scouting, personality traits, discipline 


\section{Bevezetés}

Hazánktól eltérően azokban az országokban, amelyek a világranglistán a legelőkelőbb helyet foglalják el, már évekkel ezelőtt felismerték, hogy labdarúgásuk színvonalának megtartásához, illetve emeléséhez az ifjú tehetségek komplex fejlesztésére van szükség. Ma még nem egyértelmű mindenki számára, aki a labdarúgó tehetséggondozásban tevékenykedik, hogy nemcsak a legtöbbet vizsgált faktorok (antropometriai, fiziológiai adottságok, a motoros képességek és készségek) befolyásolhatják a tehetségek kibontakoztatását, hanem a sportolók személyiségtípusai is.

Néhány sporttudományi kutatás keretében elvégzett vizsgálat eredményei (Batta, 2002; Lukács, 2006) azt mutatják, hogy a fiatal sportolók bizonyos személyiségdimenziókban eltérő értékekkel rendelkeznek, az azonos korú nem sportoló tanulókkal összehasonlítva. A különböző dimenziók mélyebb megismerése a fiatal labdarúgók esetében nemcsak a viselkedészavarok megelőzésében, hanem a nevelés eredményességének növelésében is jelentős segítséget nyújthat. A sporttudományi kutatások ezen területén kevés olyan tanulmányt találunk, ami az utánpótlás sportolók és nem sportolók személyiségjegyei közötti különbségekről szól. Ennek tudatában ez a tanulmány hasznos információkkal szolgálhat a labdarúgóutánpótlás-edzők számára a tehetségek kibontakoztatásának folyamatában.

Egy személy magatartásformáját, a viselkedését befolyásoló tényezőket már közel 2000 éve, a Galenus által megalkotott vérmérséklettípusok létrejötte óta vizsgálják a kutatók. A legutóbbi és jelenlegi században létrejött személyiségelméletek közül a típustanok és vonáselméletek próbálnak választ adni a felmerülő kérdésekre (Matolcsi, 1988). A típuselméletek alapfeltevése abban mutatkozik meg, hogy az emberek között minőségi különbség van. Ezzel szemben a vonáselméletek a mennyiséget helyezik előtérbe, folytonos vonásdimenziók alapján értékelik az egyének közötti különbségeket (Rózsa, Kö és Oláh, 2006).

Majd minden vonáselméletre és típuselméletre igaz, hogy bizonyos mértékben genetikai és biológiai szemléletü, és kisebb jelentőséget kap a környezet. Egyetértés mutatkozik azonban abban, hogy nemcsak az öröklődés determinálja a személyiséget, de ezzel együtt foglalkoznak a gének szerepével, a személyiségjegyek biológiai mechanizmusaival is (Mirnics, 2006).
$\mathrm{Az}$ emberek sok tekintetben hasonlóságot mutatnak egymással, így például a különböző biológiai és lélektani folyamatok közel megegyezően zajlanak mindannyiunknál. Más aspektusból nézve azonban mindenki különböző, hiszen a képességek, attitüdök és személyiségvonások olyan széles palettán helyezkednek el, amely egyedivé tesz minden embert (Atkinson és Hilgard, 2005).

A faktoranalitikus vizsgálatok alapgondolata az, hogy olyan személyiségdimenziók után kutat, melyeken az egyén valamelyik végponthoz közelebb van, annak függvényében, hogy melyik tulajdonság jellemzi erőteljesebben (Kozéki, 1987). A dimenziók közül az introverzió-extraverzió - melyek azt mutatják meg, hogy az egyén figyelme milyen arányban tekint önmaga, illetve a külvilág felé immár klasszikusnak számítanak, hiszen az elmúlt évtizedekben számos kutatásban alkalmazták. A skála introverzió végén a csendes, visszahúzódó, míg az extraverzió oldalon a társaságkedvelő személyeket találjuk (Atkinson és Hilgard, 2005). A tipikus extrovertált szociábilis egyén szereti az emberek közelségét és keresi a kockázatot, az izgalmakat. A tipikus introvertált személy introspekcióra, elmélkedésre hajló, elkerüli az izgalmas helyzeteket, erős önkontrollal bír, ritkán agresszív, fontos számára az erkölcsi normák betartása (Matolcsi, 1988).

Egy másik fontos dimenzió a neuroticitás, az érzelmi labilitás-stabilitás tényező pár. A magas pontszámot produkáló egyének szorongóak, hangulatuk ingadozó. Ellentétük a szorongásmentes életet élő emberek, akik inkább optimisták és nyugodtak, nem hajlamosak a lelki betegségekre (Kozéki, 1987). A stabil személyek kiegyensúlyozottak, kevésbé aggodalmaskodóak, érzelmi megnyilvánulásaik lassúak. A labilis emberek sokszor túlreagálják a stresszt, gyakran szoronganak, és nehezen nyugszanak meg (Mirnics, 2006).

$\mathrm{Az}$ úgynevezett $\mathrm{P}$ dimenzió, azaz a pszichoticizmus jelentése jól megfogható a durvalelkűség szóval. Az extraverzióval rokonságot mutat, amely leginkább abban érhető tetten, hogy a magas értékeket elérő személyek is keresik az izgalmas, veszélyes helyzeteket. Az extrovertáltakkal szemben a durvának nevezett egyén bajkeverő, nem tiszteli mások érzelmeit és érdekeit (Kozéki, 1983, 1987). A pszichoticizmus két összetevője az agresszió és a viszálykodás, mely jellemzőket hagyományosan a társadalom férfi tagjai viselik, így e személyiségvonás biológiai alapja a férfi nemi hormonokkal 
kapcsolatos (Matolcsi, 1988).

A szociális konformitás faktor egészíti ki az elözőleg kifejtett személyiségtípus-struktúrát. A magas mutatójú személyek azt szeretnék, ha maximálisan meg tudnának felelni a társadalmi elvárásoknak (Kozéki, 1987). A konformitás összetett faktor, nagyon sok dologhoz kapcsolódó társadalmi megnyilvánulás, ezáltal feltételezhető, hogy különböző vonatkozásban a nevelés kérdéseivel is összefügg (Karikó, 2008).

A mindennapi életben bármikor összefuthatunk olyan emberekkel, akik impulzív viselkedésükkel vonják magukra mások figyelmét. Ök bizonyosan magas értéket mutatnának az impulzivitás alskálán. Ezek a személyek tervezésre nem képesek, keresik az izgalmakat, de úgy, hogy „ész nélkül” vetik bele magukat veszélyes szituációkba. Ebben a magatartásformában az egyén kényszerítve érzi magát, mivel a belső kontroll alacsony szintje miatt nem maga határozza meg a tetteit, hanem a körülmények. A céltudatos cselekvés folyamatában az egyén határozza meg a célt, azt magas belső kontrollja irányítja. Ez a jellemzője az erőfeszítéssel, kitartással végzett tevékenységeknek (Kozéki, 1981, 1983, 1987).

Az elnevezésből következik, hogy a kockázatvállaló bátran vállalja a kockázatot. Ez a dimenzió, hasonlóan az impulzivitáshoz, az extraverzióból vált önállóvá. A kockázatvállaló szereti az új impulzusokat, vonzódik a kihívásokhoz. Ezek az emberek tisztában vannak a kockázat súlyával és tudatosan vállalják azt (Kozéki, 1988).

A behelyettesítő tapasztalat egyik válfaja a behelyettesítő (vikariáló) érzelmi arousal, azaz az empátia. Ez akkor lép fel, ha külső megfigyelőként magunk is átéljük ugyanazt az érzelmet (Carver és Scheier, 2006). Az empátiában magas értéket mutató személy megérti mások érzelmi állapotát, képes együttérzésre, tapintatos (Kozéki, 1988).

A személyiség magatartását determináló belső feltételrendszer legmagasabb eleme a jellem. Ettől a személyiségbeli képződménytől az erkölcsi magatartásformák függnek a leginkább. Ezért fontos az egyén jellemének a behatóbb megismerése, mert a pedagógiai törvényszerűségeket alkalmazhatóvá teszi az erkölcsi magatartás formálásának során (Bábosik, 1991). A sporttevékenység folyamatában az edzőknek lehetőségük van arra, hogy a sportolók morális magatartását megfelelő irányba tereljék, ugyanis bizonyos pozitív jellemvonások birtoklása nélkül nem valósulhatnak meg a kiemelkedő sportteljesítmények (Biróné, 2004). A sportoló tehetsége a teljesítményben nyilvánul meg. Jelentősen befolyásolja a jellemvonásainak fejlesztése azt, hogy képes lesz-e kiemelkedő eredményre (Kozéki, 1987).

Vizsgálatunk célja, hogy az Eysenck nevéhez köthető személyiségtesztek segítségével, számadatokkal állapítsuk meg a fiatal labdarúgók személyiség-dimenzióikhoz kapcsolódó értékeit, összehasonlítva azokat a nem rendszeresen sportoló fiatalok adataival. A kimutatható eredmények ismerete alapján az edzők célirányosan alkalmazhatják a sportolók személyiségfejlesztésében a különböző pedagógiai módszereket és nevelési attitűdöket.

\section{Módszerek}

\section{A vizsgált minta jellemzése és az adatfelvétel körülményei}

Kutatásunkat Magyarország nyolc elit labdarúgó akadémiájának egyikében végeztük. A teszteket négy különböző korosztály $(15,16,17$ és 18 éves fiúk) töltötte ki, az intézmény kollégiumában bentlakó labdarúgók és a nem rendszeresen sportoló diákok. Mindannyian az akadémia saját középiskolájában tanulnak. Az akadémiát irányító testület jóváhagyta a kutatáshoz tartozó etikai és módszertani faktorokat. A 18 év alatti gyerekek szülei írásban járultak hozzá a vizsgálatban való részvételhez, míg a már nagykorú sportolók maguk írták alá a beleegyező nyilatkozatot.

A teszteket a labdarúgók 2016. március elején a versenyidőszakban, a tanítási órák után, a délutáni tanulószobán töltötték ki, míg a nem rendszeresen sportoló diákok ugyanebben az időintervallumban, a testnevelésórán tették ezt meg. Az adatfelvételt a szerzők közül egy fö, valamint egy kollégiumi nevelő és a testnevelő tanár felügyelte. Mindannyian segítettek abban, hogy a tesztek lényegét a fiúk megértsék, valamint válaszoltak a felmerülő kérdésekre.

Betegség miatt csak négy személy hiányzott a mintából, a többiek az intézményben tartózkodtak ebben az időszakban. Összesen 172 fiú válaszát dolgoztuk fel, ebből 72 fó labdarúgó a 15 éves $(\mathrm{n}=23)$, a 16 éves $(n=16)$, a 17 éves $(n=19)$ és a 18 éves ( $\mathrm{n}=14)$ korosztályból, valamint 100 fó azonos korú nem rendszeresen sportoló fiú ( 15 évesek $n=42 ; 16$ évesek $\mathrm{n}=23 ; 17$ évesek $\mathrm{n}=24 ; 18$ évesek $\mathrm{n}=11$ ). A labdarúgók átlagéletkora $M=16,30 \pm 1,26$, a nem rendszeresen sportolóké pedig $M=16,04 \pm 1,05$. Az átlagéletkor a teljes minta alapján $M=16,16 \pm 1,09$. 


\section{Alkalmazott tesztek}

1. Hungarian Junior Eysenck Personality Quastionnaire (HJEPQ)

A típustanok és vonáselméletek egyik kimagasló képviselője H. J. Eysenck, akinek a mérési módszerei közé tartozik az Eysenck Personality Quastionnaire (EPQ) kérdőív, melynek magyar adaptációja (HEPQ) 1982-ben készült el Matolcsi Ágnes munkája nyomán, míg a gyermekek számára készült változat (HJEPQ) Kálmánchey és Kozéki nevéhez köthető. Az egyéni és csoportos vizsgálatra is alkalmazható papír-ceruza kérdőív négy személyiségdimenziót: az extraverziót, a neuroticizmust, a pszichoticizmust és a szociális konformitást (vagy hazugságot) különböztet meg, ez utóbbi a teszt megbízhatóságának az ellenőrzését is lehetővé teszi, melyekhez 86 kérdés társul. Az extraverzió azt mutatja, hogy az egyén milyen mértékben keresi az izgalmakat, a kockázatot.

A pszichoticizmus alskála a vizsgált személy agresszív, ellenséges magatartásáról szolgál információval. A neuroticizmus dimenzió azt méri, hogy az egyén emocionálisan milyen fokon kontrollált. A szociális konformitás vagy hazugság alskála korábban a teszt kitöltése megbízhatóságának ellenőrzésére szolgált.

Később Eysenck megállapította, hogy a skála mögött a társadalmi elvárásoknak megfelelö magatartás vállalásának igénye is megbújhat (Matolcsi, 1988).

\section{Hungarian Eysenck Impulsivennes -} Venturesomeness - Empathy Quastionnaire (HEIVEQ); „Impulzivitás - kockázatvállalás - empátia" kérdöiv (IKE)

Az Eysenck-féle „Impulzivitás-kockázatvállalásempátia” kérdőív adaptációja a Hungarian Eysenck Impulsivennes-Venturesomeness-Empathy Quastionnaire (HEIVEQ) 1984-ben készült el, Kozéki Béla munkája nyomán (Kozéki, 1988). A kérdőív - ami 3, egyenként 23 itemet magában foglaló alskálából áll - szintén alkalmas egyéni és csoportos vizsgálatra. A vizsgált személyek a tételek végén található „igen” vagy „nem” szó közül választhatnak. Ez a kérdőív a személyiség dimenzionális elméletére épült eszközsor tagja, mely három alapvető személyiségdimenziót mér. Az impulzivitást, mely a meggondolatlan viselkedést fejezi ki, a kockázatvállalást, amely a kihívás kedveléséről tanúskodik, valamint az együttérzést kifejező empátiát (Kozéki, 1988).

\section{Adatelemzés}

Vizsgálatunkban az SPSS for Windows 20.0 statisztikai programot használtuk. A minta jellemzéséhez a leíró statisztikát, a labdarúgó és nem labdarúgó csoportok közötti különbségek bemutatásához kétmintás T próbát alkalmaztunk. Szignifikancia szintnek a társadalomtudományokban leggyakrabban alkalmazott 5\%-os hibahatárt vettük alapul.

1. táblázat: HJEPQ-, HEIVEQ-kérdőívek eredményei labdarúgók és nem sportolók mintájában [forrás: saját szerkesztés]

\begin{tabular}{|c|c|c|c|c|c|}
\hline $\begin{array}{c}\text { HJEPQ alskálák } \\
\text { HEIVEQ }\end{array}$ & $\begin{array}{l}\text { Labdarúgó } \\
(\mathrm{N}=72) \\
\text { átlag } \pm \text { szórás }\end{array}$ & $\begin{array}{l}\text { Nem-sportoló } \\
\qquad(\mathrm{N}=100) \\
\text { átlag } \pm \text { szórás }\end{array}$ & $\begin{array}{c}\sum(\mathrm{N}=172) \\
\text { átlag } \pm \text { szórás }\end{array}$ & $\mathbf{t}$ & $\mathbf{p}$ \\
\hline Átlagéletkor & $16,30 \pm 1,26$ & $16,04 \pm 1,05$ & $16,16 \pm 1,09$ & - & - \\
\hline Extraverzió $^{*}$ & $17,96 \pm 3,13$ & $15,30 \pm 3,66$ & $16,42 \pm 3,68$ & 4,96 & 0,00 \\
\hline Neuroticizmus* & $9,44 \pm 4,13$ & $11,88 \pm 4,12$ & $10,86 \pm 4,29$ & $-3,81$ & 0,00 \\
\hline Pszichoticizmus & $7,40 \pm 1,75$ & $7,60 \pm 1,94$ & $7,51 \pm 1,86$ & $-0,68$ & 0,49 \\
\hline $\begin{array}{c}\text { Szociális } \\
\text { konformitás* }\end{array}$ & $7,85 \pm 3,39$ & $9,04 \pm 3,84$ & $8,54 \pm 3,70$ & $-2,07$ & 0,04 \\
\hline Impulzivitás & $11,52 \pm 4,40$ & $12,53 \pm 4,40$ & $12,11 \pm 4,41$ & $-1,48$ & 0,14 \\
\hline Kockázatvállalás* & $18,36 \pm 3,48$ & $15,11 \pm 4,08$ & $16,47 \pm 4,15$ & 5,46 & 0,00 \\
\hline Empátia & $13,81 \pm 3,70$ & $13,58 \pm 4,12$ & $13,68 \pm 3,93$ & 0,38 & 0,69 \\
\hline
\end{tabular}




\section{Eredmények}

A vizsgálati eredmények szignifikánsan magasabb értéket mutatnak az extraverzió dimenzióban a labdarúgók javára $(M=17,96 \pm 3,13)$, a nem labdarúgókkal szemben. A neuroticizmus alskálán is jelentős különbséget találunk, azonban itt a nem sportolók javára $(\mathrm{M}=11,88 \pm 4,12)$, ami azt jelenti, hogy érzelmileg labilisabbak.

A magasabb szociális konformitás-mutatóval rendelkező nem labdarúgók $(M=9,04 \pm 3,84)$ erőteljesebben szeretnének megfelelni a társadalmi elvárásoknak. A pszichoticizmus faktorban és a hozzá közel álló impulzivitás tényezőben, valamint az empátia dimenzióban nem lelhető fel értékelhető különbség.

A kockázatvállalásban, hasonló módon az extraverzió alskálához, szignifikáns eltérést találunk a labdarúgók javára $(M=18,36 \pm 3,48)$.

\section{Megbeszélés}

A labdarúgók és a nem rendszeresen sportolók eredményei alapján megállapíthatjuk, hogy statisztikailag szignifikáns különbség mutatkozik több dimenzió tekintetében is. A labdarúgók oldalán magas extraverzió értéket találunk, tehát a nem aktívan sportolók introvertáltabbak, vagyis kevésbé szeretik az izgalmakat, a váratlan szituációkat, érzelmeiket szorosabb kontroll alatt tartják, visszafogottabban viselkednek, fegyelmezettebbek.

A kockázatvállalás, mely rokon vonásokat mutat az extraverzióval, eredményeit összehasonlítva megállapíthatjuk, hogy a labdarúgók átlagértékei magasak, tehát szeretik az újszerủ helyzeteket, a kihívásokat, az erős benyomásokat, tudatosan választják a veszélyt, de vállalják azt. A két csoport között meglévő eltérés a neuroticizmus alskálában is tetten érhető.

A nem rendszeresen sportoló fiatalok nagyobb értékei azt jelentik, hogy érzelmileg labilisabb személyek, érzékenyek, szorongóak, hangulatuk ingadozó, könnyen válnak lehangolttá, depresszióssá. $\mathrm{Az}$ alacsonyabb szociális konformitás-mutatóval rendelkező labdarúgók viselkedése kevésbé felel meg a társadalmi ideálnak, kisebb mértékben érdekli őket mások véleménye, többször követnek el normaszegést.

A tanulmány eredményei alapján elmondható, hogy a fiatal elit labdarúgók bizonyos személyiségjegyei jelentősen eltérnek a nem labdarúgókétól.
Az utánpótlás edzőknek figyelembe kell venni a személyiségdimenziókkal kapcsolatos azon tényt, hogy a sportolókra más személyiségtípus jellemző, emiatt érdemes különböző nevelési módszereket alkalmazniuk a tehetséggondozási folyamat során.

A labdarúgó és a nem aktívan sportoló csoportok közötti dimenziók értékeinek különbsége miatt a megfelelol nevelési hatásrendszer alkalmazása a serdülők körében felértékelődik.

A közeli jövőben tervezzük, hogy a személyiségdimenziókról meglévő információk bővítésének céljából a kutatás további menetében más intézményben is elvégezzük vizsgálatainkat.

\section{Irodalom}

1. Atkinson, R.C. és Hilgard, E. (2005): Pszichológia. Osiris Kiadó Kft., Budapest.

2. Batta Klára (2002): A tornasport nevelo" hatásának empirikus vizsgálata. PhD értekezés, Semmelweis Egyetem Testnevelési és Sporttudományi Kar, Nevelés- és Sporttudomány Tudományági Doktori Iskola, Budapest.

3. Bábosik István (1991): A nevelés folyamata és módszerei. Leopárd Könyvkiadó, Budapest.

4. Biróné Nagy Edit (szerk.) (2004): Sportpedagógia. Kézikönyv a testnevelés és sport pedagógiai kérdéseinek tanulmányozásához. Dialóg Campus Kiadó, Pécs.

5. Carver, C.S. és Scheier, M.F. (2006): Személyiségpszichológia. Osiris Kiadó Kft, Budapest.

6. Karikó Sándor (2008): Konformitás és nevelés. Okker Kft., Budapest.

7. Kozéki Béla (1981): Önállóság, önfegyelem autonómia. Tankönyvkiadó, Budapest.

8. Kozéki Béla (1983): A fegyelmezett személyiség kialakitása. Tankönyvkiadó, Budapest.

9. Kozéki Béla (1987): Moralitás, jellemfejlesztés. Tankönyvkiadó, Budapest.

10. Kozéki Béla (1988): Az Eysenck-féle „Impulzivitás - Kockázatvállalás - Empátia" kérdőív iskoláskorúak részére. In: Mérei Ferenc és Szakács Ferenc (szerk.). Pszichodiagnosztikai Vademecum. I. Explorációs és biográfiai módszerek, tünetbecslö skálák, kérdöivek. 2. rész. Tankönyvkiadó, Budapest. 301-319.

11. Lukács Liza (2006): Pszichológiai mérések I. www.sportpszichologia.eu (Letöltés: 2016. július 12.)

12. Matolcsi Ágnes (1988): Az Eysenck-féle személyiség kérdőív (EPQ) felnőtt változatának 
hazai adaptációja. In: Mérei Ferenc és Szakács Ferenc (szerk.). Pszichodiagnosztikai Vademecum. I. Explorációs és biográfiai módszerek, tünetbecslö skálák, kérdöivek. 2. rész. Tankönyvkiadó, Budapest. 270-282.

13. Mirnics Zsuzsanna (2006): A személyiség épitőkövei. Bölcsész Konzorcium, Budapest.

14. Rózsa Sándor, Kő Natasa és Oláh Attila (2006): Strukturált személyiség-kérdőívek. In: Rózsa Sándor, Nagybányai Nagy Olivér és Oláh Attila (szerk.). A pszichológiai mérés alapjai. Bölcsész Konzorcium, Budapest. 221-255.

15. Williams, M.A. és Franks, A. (1998): Talent identifiction in soccer. Sport, Exercise and Injury, 4: 159-165. 